\title{
Co přinášejí pro klinickou praxi mezinárodní aktivity Less is more a Choosing wisely?
}

V moderním pojetí medicíny se stále zpřesňuje diagnostika, rozšiřuje definice chorob a to indukuje stále narůstající zátěž pro zdravotní systémy, ale i pro celou populaci. Ukazuje se, že ne všechen posun, realizovaný díky novým vyšetřovacím metodám a léčebným postupům, je pro nemocné prínosem. V editorialu vysvětluji, v čem spočívají hnutí Less is more a Choosing wisely, která se snaží některé nadužívané postupy ve prospěch pacientů racionalizovat.

Koncept Less is More byl iniciován v USA v roce 2010. Jeho úkolem bylo upozornit na potenciální rizika nadbytečného užívání diagnostických a terapeutických postupů, které mohou nemocným přinášet větší poškození než predpokládaný užitek. Tím se zpochybnil často mylně předjímaný předpoklad, že více péče je vždycky prínosem. Jako reakce se objevily aktivity jednotlivých odborných společností, nazývané Choosing wisely (tedy volně - Rozumná volba), kde většina odborných společností vytipovala několik nejvíce nadužívaných postupů z oblasti své odbornosti, které je třeba volit přinejmenším uvážlivě. Nicméně implementace těchto aktivit do praxe naráží zejména v evropských zemích na překážky, které jsou historicky ve společnosti zakořeněny a těžko se překonávají. Pacienti mají vysoká očekávání a tomu se přizpůsobuje chování lékařů podporované často i finančními zájmy z nejrůznějších stran. Studie např́klad prokazují, že lékaři často indikují vyšetření dalším specialistou, krevní testy, zobrazovací metody a předepisuji léky prímo na prání pacientů, kterým ve vysoce převažujícím procentu prípadů raději vyhoví. Vše pak má negativní dopad na možnost omezení naduživání některých diagnostických a léčebných metod. I v nejbohatších státech Evropy jsou již problémy profinancovat takto vedenou zdravotní péči a situace se bude se stárnutím populace a nárůstem obezity a tedy i s ní spojené morbidity dále zhoršovat. V současné době kvalifikované odhady upozorňují, že 22-30 \% zdravotní péče může být považováno za nadbytečnou.

Po celé roky je společnosti vštěpována idea, že zdravotní péče je klíčem k udržení zdraví a čím více prohlídek, tím lépe. Navíc pacienti nechápou, že každá diagnostická a léčebná aktivita má svá úskalí a často je lepším lékařem ten, který na základě zhodnocení prínosů a rizik nepodnikne žádnou aktivní diagnostickou a léčebnou intervenci. Nicméně nemocní si spíše cení lékaře, který aktivně, často zbytečně, vyšetřuje. Menší aktivita lékaře je spišse vykládána jako nezájem nebo zanedbávání, či snaha ušetřit náklady. Je totiž stále laikům zdůrazňována nutnost včasné diagnózy, ale nehovoři se o častých negativních důsledcích falešně pozitivních nálezů. Lékaři mají spíše tendenci nesdělovat nemocným plný rozsah rizik diagnostických a léčebných postupů, což vede k nadhodnocení prínosu aktivního postupu a je to také již nazýváno "Therapeutic illusion“. Klíčové je tedy s nemocným hovořit o rizicích a prínosech plánované aktivity a dojít s ním ke konsenzuálnímu závěru a k určitému rozdělení zodpovědnosti za přijaté řešení.

Roste množství důkazů, že medicína škodí zdravým lidem tím, že se snaží o stále dřivější detekci onemocnění a rozšiřování definice patologií. Vědecké studie přinášejí důkazy, že mnoho osob je „přeléčeno“, předávkováno a „přediagnostikováno“ (overtreated, overdosed and overdiagnosed). Síly, které za tímto trendem stojí, jsou hluboce zakořeněny jak v medicíně, tak ve společnosti. To významně ztěžuje zastavení tohoto nezdravého vývoje. Klíčovým faktorem je také technologický pokrok. Schopnost zjistit malé abnormity vede ke zvýšení prevalence určitých onemocnění. Léčba těchto nezávažných forem chorob pak vede k nadhodnocení účinků príslušné terapie a tak je bludný kruh uzavřen. Skríningové programy detekuji časná stadia nádorů, které by nikdy nebyly symptomatické ani nezkrátily život, citlivé diagnostické metody identifikují abnormality, které by zůstaly benigní. Rož̌iřování definice patologií snižováním hranic, kdy je stav již prohlášen za onemocnění, vede k tomu, že mnoho osob s velmi nízkým rizikem dostává trvalou nálepku určité choroby a medikaci, která jim nijak neprospívá. Toto rozšíření hranic pro diagnózu chorob schvaluje panel expertů, kteř́i jsou úzce propojeni s farmaceutickým průmyslem. Je odhadováno, že taková zbytečná léčba stojí v USA ročně 200 miliard dolarů a navíc působí nemalé zdravotní škody.

Z randomizovaných studií je patrné, že osoby, které se podrobily skríningu některých malignit, z léčby neprofitují a ve srovnání s ostatní populací není žádný mortalitní rozdíl. Autopsie také ukazují, že v populaci je velký rezervoár subklinických forem onemocnění, zejména nádorů prostaty, prsu a štítné žlázy, které zůstaly asymptomatické. Podobně užití moderních diagnostických metod v kardiologii u nízkorizikových nemocných vede k přediagnostikování koronární aterosklerózy a k řadě revaskularizací, které nemaji žádný význam. Diagnostické zobrazovací metody břicha, malé pánve, hrudníku a páteře mohou objevit náhodné abnormality. Jen velmi malý počet osob může profitovat z časného odhalení zhoubných nádorů, ale mnohem větší část trpí zbytečnou úzkostí a nežádoucími reakcemi během dalších indukovaných diagnostických a léčebných metod.

Objektivní analýzy v ambulantní praxi ukazují, že lékaři spíše zavádějí nové prístupy k diagnostice a léčbě, ale doporučení k opuštění zbytečných postupů není respektováno. Velkou roli v nadužívání metod hraje obava ze stížnosti nebo dokonce žaloby pacienta nebo jemu blízkých osob. V nemocniční péči hrají roli i nově zavedené akreditace, kde se s využitím všech možných metod nemocnice snaží obhájit svou pozici špičkového pracoviště. Částečně na vině jsou i doporučené postupy, které jsou často založeny na studiích souborů vybraných pacientů, kteří neodpovídají běžné klinické praxi, a pak jsou závěry zobecněny 
na mnohem širší okruh nemocných. Někdy je podkladem doporučení jen mínění expertů. Byly mnohokrát přineseny důkazy, že v USA, kde se jich většina formuluje, byly doporučené postupy výrazně ovlivňovány finančními dary farmaceutických firem členům expertních komisí a tak jsou často guidelines odkloněny od medicíny založené na důkazech.

Lékaři věnující se určitým specializacím mají zájem rozšiřovat okruh svých pacientů a těžko prijímají výsledky studií, které zpochybňují prospěšnost jimi použivaných postupů. Svoji roli v mysli lékarư hrají i nezodpovědná expertní rozhodnutí soudních znalců posuzujících prípady často ne zcela blízké jejich specializaci. Je tendence prípad posuzovat ex post, tedy znalec již zná závěrečnou diagnózu a nepostupuje v diagnostické rozvaze s lékařem, množstvím a kvalitou jeho informací v okamžik, kdy Činil určité rozhodnutí. Expert má pak pocit, že diagnóza nebyla včas nebo správně stanovena, a vyslovuje neodůvodněný závěr o postupu non lege artis. Poškození z „přediagnostikování” se většinou naopak neřeší, protože v tomto prípadě stižnost většinou není podána. Intuitivní víra, že časná detekce onemocnění je jednoznačně prospěšná je v centru problému.
Dalším důvodem k neefektivnímu nadužívání zdravotní péče je její fragmentace. Vyhraňující se specializace vede k tomu, že o jednoho polymorbidního nemocného často pečuje řada specialistů, což vede nejen k nadbytečným klinickým vyšetřením, duplicitnímu použití vyšetrovacích metod a často i nebezpečné polypragmazii vedoucí k lékovým interakcím. Zdravotnické systémy založené na bazi "fee for service", tedy odměny za odvedenou práci, finančně více motivují k naduživání metod. Na druhé straně fixní platy lékařu nebo pevná sazba za klinické vyšetření vytváří pozitivnější atmosféru k omezení zbytečných výkonů.

Primárním cílem kampaně „Les is More“ však není predevším omezení nákladů zdravotnických systémů, ale racionální užití současných možností moderní medicíny tak, aby její nadužívání nepoškozovalo pacienty, což se nyní již „,bohužel“ často děje. Seznámení naší odborné veřejnosti s tímto tématem považujeme za velice př́nosné. Konkrétní, důležité a časté príklady pohledu na problematiku "Méně je více“ a „Rozumnou volbu“ z oblasti interního lékařství přinášejí 3 sdělení v rámci hlavního tématu tohoto čísla.

\section{LITERATURA}

1. The challenge of implementing Less is More medicine : A European perspective. Omar Kherad, Nathan Peiffer-Smajda, et al. Eur J Intern Med. 2020 Jun; 76: 1-7. doi: 10.1016/j. ejim.2020. 04. 014.

2. Preventing overdiagnosis: how to stop harming the healthy Ray Moynihan, Jenny Doust and David Henry. BMJ 2012; 344: e3502, doi: 10.1136/bmj.e3502.

MUDr. Luboš Kotík, CSc. Interní klinika Fakultní Thomayerova nemocnice, Praha 